\title{
THE GENERALIZED MODEL OF SITUATIONAL PRIORITIES IN ACCESS SYSTEMS
}

\author{
Leonid O. Uryvsky, Hanna S. Hakhova \\ National Technical University of Ukraine "Igor Sikorsky Kyiv Polytechnic Institute", Kyiv, Ukraine
}

Objective. Under conditions of limited resources queuing system (QS) with disciplines of different priorities are a powerful conflict-resolving tool. The aim of the paper is to generalize the model of situational priority service based on QS with two streams for one or two servicing devices, and to offer possible scenarios for implementation of situational priorities in access systems.

Methods. The generalized analytical model of queuing system was realized according to the Markov chains theory. This model substantiates the best scenarios that justify the situational priorities implementation.

Results. The result is an analytical description of the generalized model of QS with two streams for one or two servicing devices and the quantitative analysis of scenarios implementation of service priority in access systems. The performance analysis for each stream and overall QS performance was conducted. The recommendations for effective usage of priority service disciplines based on the proposed scenarios were given.

Conclusions. One of the possible scenarios of situational priorities algorithm implementation was proposed based on the mathematical resource access model. The points of priority change by the selected value of system productivity were illustrated based on the quantitative data.

Keywords: access system; queuing system; situational priorities; productivity.

\section{Introduction}

Queuing system (QS) with priority service is a tool to resolve conflicts related to the request servicing resource limitations due to different significance or different nature of the messages [1-3].

For example, requests coming to establish a voice communication session belong to higher $\left(1^{\text {st }}\right)$ priority and requests coming to organize the data channel belong to lower $\left(2^{\text {nd }}\right)$ priority. The attempt to establish a connection to transfer the message of the appropriate type is registered as request of QS service.

The different variants of the priority service (absolute, relative, combined, re-servicing) have distinct characteristics and mathematical models that allow calculating the characteristics of the systems [24]. If the functioning conditions are changing in the QS, it is important for each case to be able to choose the best option for request-selecting criteria.

\section{Situational priorities (SP)}

The situational priorities present a separate group of QS with priorities, where the choice of priority discipline in the current time depends on the current state of QS (the current situation) [2].

The waiting state is characterized by vector $x=\left(x_{1}, x_{2}, \ldots, x_{N}\right)$ where $x_{i_{-}}$the number of requests i-type in the system. Set of these vectors with integer components forms the system states space. $x=\left\{x=\left(x_{1}, x_{2}, \ldots, x_{N}\right)\right\}$.

Let us assume that all this space is divided into disjoint sets $x_{k}(k=\overline{0, N}), x=\bigcup_{k=0}^{N} x_{k}, x_{k} \cap x_{s}=\emptyset$, $k \neq s$.

The control strategy is defined for each such division $x=\left\{x_{k}, k=\overline{0, N}\right\}$ $x=\left\{x_{k}, k=\overline{0, N}\right\}$. If the system is in state of subsets $x_{k} x_{k}$ in the moment of making the control decision, the $V=V\left(x_{k}\right)=k$ control is assumed. Control moments restriction is set depending on the system type. The system where control strategy is decided in the stated way is called SP system.

The different service variants have their independent mathematical models that allow the systems' characteristics to be calculated [1].

Therefore, let us analyze the mathematical model of telecommunication system resource access with SP models. 


\section{Problem formulation}

Let us consider the QS with one servicing device and two input streams of same or different priorities that have numeric characteristics of requests input intensity $(\lambda 1, \lambda 2)$ and request service intensity $(\mu 1, \mu 2)$.

The model that combines all known QS request service types [4] is presented as a state graph in Fig.1.

If we exclude the «2-1» state from the graph, we have the system without priorities.

The variables $\lambda 12, \mu 21$ and $\mu 22$ are the instruments of the priority system situational control in the state graph that shows the generalized QS (Fig.1):

1. The system with two streams without priorities and with one servicing device:

$$
\lambda_{12}=0 ; \mu_{21}=1 ; \mu_{22}=0 \text {. }
$$

2. The system with the absolute priority (with absolute servicing break by the higher request) should fulfill these conditions:

$$
\lambda_{12}=\lambda_{1} ; \mu_{21}=\infty ; \mu_{22}=0
$$

3. The system with the relative priority (with servicing break by the lower request servicing finish) should fulfill these conditions:

$$
\lambda_{12}=\lambda_{1} ; \mu_{21}=\mu_{2} ; \mu_{22}=0 \text {. }
$$

The system with the combined priority (with current lower request servicing break by the $\Delta \mathrm{t}_{0}$ time interval) should fulfill these conditions:

$$
\lambda_{12}=\lambda_{1} ; \mu_{21}^{*}=\frac{\mu_{2}}{1-e^{-\Delta t_{0} \mu_{2}}} ; \mu_{22}=0 .
$$

The re-servicing system (with the current lover request servicing resumption after a break):

$$
\lambda_{12}=\lambda_{1} ; \mu_{21}=0 ; \mu_{22}=\mu_{1} \text {. }
$$

\section{Generalized QS description}

Let us find the possibility of servicing device idleness $P_{0}$. To do this, let us create the equations system:

$$
\left\{\begin{array}{l}
P_{0}\left(\lambda_{1}+\lambda_{2}\right)=P_{1} \cdot \mu_{1}+P_{2} \cdot \mu_{2} \\
P_{1} \cdot \mu_{1}=P_{0} \cdot \lambda_{1}+P_{2-1} \cdot \mu_{21} \\
P_{2}\left(\mu_{2}+\lambda_{12}\right)=P_{0} \cdot \lambda_{2}+P_{2-1} \cdot \mu_{22} \\
P_{2-1}\left(\mu_{21}+\mu_{22}\right)=P_{2} \cdot \lambda_{12} \\
P_{0}+P_{1}+P_{2}+P_{2-1}=1
\end{array}\right.
$$

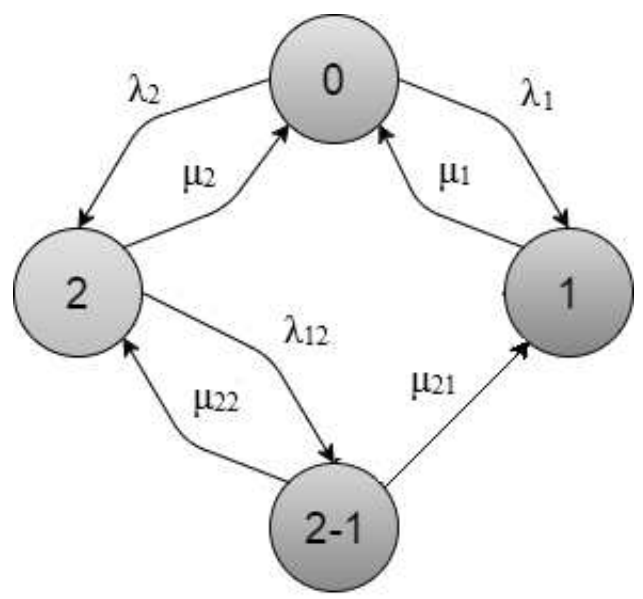

Fig.1 Generalized QS with two streams and one servicing device

Let us convey the possibilities of generalized state graph: $P_{1}, P_{2}, P_{2-1}$ through the possibility of state $P_{0}$ and we will get:

$$
\begin{gathered}
P_{1}=P_{0} \cdot \rho_{1}+P_{0} \cdot \frac{\lambda_{2} \cdot \mu_{21} \cdot \lambda_{12}}{\left(\mu_{2}+\lambda_{12}-\frac{\lambda_{12} \cdot \mu_{22}}{\mu_{12}} \mu_{12} \cdot \mu_{1}\right.} \\
P_{2}=P_{0} \cdot \frac{\lambda_{2}}{\left(\mu_{2}+\lambda_{12}-\frac{\lambda_{12} \cdot \mu_{22}}{\mu_{12}}\right)} \\
P_{2-1}=P_{0} \cdot \frac{\lambda_{2} \cdot \lambda_{12}}{\left(\mu_{2}+\lambda_{12}-\frac{\lambda_{12} \cdot \mu_{22}}{\mu_{12}}\right) \mu_{12}}
\end{gathered}
$$

where $\mu_{12}=\mu_{21}+\mu_{22}$.

Let us put the obtained values into the norming condition:

$$
P_{0}+P_{1}+P_{2}+P_{2-1}=1
$$

Therefore, the possibility of servicing device idleness $P_{0}$ in the case of generalized QS:

$$
\begin{aligned}
& P_{0}=\frac{1}{1+\rho_{1}+\frac{\lambda_{2} \cdot \mu_{21} \cdot \lambda_{12}}{\left(\mu_{2} \cdot \mu_{12}+\lambda_{12} \cdot \mu_{21}\right) \mu_{1}}+\frac{\lambda_{2}}{\left(\mu_{2} \cdot \mu_{12}+\lambda_{12} \cdot \mu_{21}\right)}}+ \\
& +\frac{1}{\left(\mu_{2} \cdot \mu_{12}+\lambda_{12} \cdot \mu_{21}\right)}
\end{aligned}
$$

Let us make sure that this formula suits the models of known QS types when different conditions are considered. 
1. The system without priorities with two streams and one servicing device:: $\lambda_{12}=0 ; \mu_{21}=1$; $\mu_{22}=0$.

When we put these conditions into (12), we will get (13):

$$
P_{0}=\frac{1}{1+\rho_{1}+\frac{\lambda_{2}}{\mu_{2}}}=\frac{1}{1+\rho_{1}+\rho_{2}}
$$

2. The system with the relative priority should fulfill these conditions:

$$
\begin{aligned}
& \lambda_{12}=\lambda_{1} ; \mu_{21}=\mu_{2} ; \mu_{22}=0 . \\
& \text { Then from }(12) \text { we will get (14): } \\
& P_{0}=\frac{1}{1+\rho_{1}+\frac{\lambda_{2} \cdot \mu_{2} \cdot \lambda_{1}}{\left(\mu_{2}+\lambda_{1}\right) \mu_{2} \cdot \mu_{1}}+\frac{\lambda_{2}}{\mu_{2}+\lambda_{1}}+\frac{\lambda_{2} \cdot \lambda_{1}}{\left(\mu_{2}+\lambda_{1}\right) \mu_{2}}}= \\
& =\frac{1}{1+\rho_{1}\left(1+\frac{\lambda_{2}}{\lambda_{1}+\mu_{2}}\right)+\frac{\lambda_{2}}{\lambda_{1}+\mu_{2}}\left(1+\frac{\lambda_{1}}{\mu_{2}}\right)}
\end{aligned}
$$

3. The system with the absolute priority should fulfill these conditions:

$$
\lambda_{12}=\lambda_{1} ; \mu_{21}=\infty ; \mu_{22}=0 \text {. }
$$

Then from (12) we will get (15):

$$
P_{0}=\frac{1}{1+\rho_{1}+\frac{\lambda_{2} \cdot \lambda_{1}}{\left(\mu_{2}+\lambda_{1}\right) \mu_{1}}+\frac{\lambda_{2}}{\mu_{2}+\lambda_{1}}}=\frac{1}{\left(1+\rho_{1}\right)\left(1+\frac{\lambda_{2}}{\lambda_{1}+\mu_{2}}\right)}
$$

4. The system with the combined priority should fulfill these conditions:

$$
\lambda_{12}=\lambda_{1} ; \mu_{21}^{*}=\frac{\mu_{2}}{1-e^{-\Delta t_{0}} \mu_{2}} ; \mu_{22}=0 \text {. }
$$

Then from (12) we will get (16):

$$
\begin{aligned}
& P_{0}=\frac{1}{1+\rho_{1}+\frac{\lambda_{2} \cdot \mu_{2} \cdot \lambda_{1}}{\left(\mu_{2}+\lambda_{1}\right) \mu_{2} \cdot \mu_{1}}+\frac{\lambda_{2}}{\mu_{2}+\lambda_{1}}+\frac{\lambda_{2} \cdot \lambda_{1}}{\left(\mu_{2}+\lambda_{1}\right) \mu_{21}^{*}}}= \\
& =\frac{1}{1+\rho_{1}\left(1+\frac{\lambda_{2}}{\lambda_{1}+\mu_{2}}\right)+\frac{\lambda_{2}}{\lambda_{1}+\mu_{2}}\left(1+\frac{\lambda_{1}}{\mu_{21}^{*}}\right)}
\end{aligned}
$$

5. The re-servicing system:

$$
\lambda_{12}=\lambda_{1} ; \mu_{21}=0 ; \mu_{22}=\mu_{1} \text {. }
$$

Then from (12) we will get (17):

$$
\begin{aligned}
& P_{0}=\frac{1}{1+\rho_{1}+\frac{\lambda_{2}}{\left(\mu_{2}+\lambda_{1}-\frac{\lambda_{1} \cdot \mu_{1}}{\mu_{1}}\right)}+\frac{\lambda_{2} \cdot \lambda_{1}}{\left(\mu_{2}+\lambda_{1}-\frac{\lambda_{1} \cdot \mu_{1}}{\mu_{1}}\right) \mu_{1}}} \\
& =\frac{1}{1+\rho_{1}+\rho_{2}+\rho_{1} \cdot \rho_{2}}
\end{aligned}
$$

Considering the designations used above, in particular, (1) - (5), the generalized formulae (12) can be simplified (18):

$$
P_{0}=\frac{1}{1+\rho_{1}+\frac{\rho_{2}}{\left(\mu_{12}+\frac{\lambda_{12}}{\mu_{2}} \cdot \mu_{21}\right)} \cdot\left\{\mu_{12}+\lambda_{12} \cdot\left[1+\frac{\mu_{21}}{\mu_{1}}\right]\right.}
$$

Therefore, the formula (18) is a generalized QS description with five independent request servicing types, where the variables $\lambda_{12}, \mu_{21}$ and $\mu_{22}$ are the instruments of priority system situational control.

\section{Situational priorities realization scenario}

Let us consider the QS with two servicing devices and two input streams of same or different priorities that have numeric characteristics of requests input intensity $(\lambda 1, \lambda 2)$ and request servicing intensity $(\mu 1, \mu 2)$.

Let us write the basic scenario of SP realization in the access system based on four servicing disciplines: without priorities, relative priority, absolute priority and re-servicing.

For SP the priority type selection depends on the scenario (the intensivities ratio) and on the superiority criterion (e.g. productivity, loss probability, waiting time and so on).

Let us model the situation where there are two input streams in the QS with two servicing devices.

$1^{\text {st }}$ stream - high quantity of short messages (for example, emergency messages);

$2^{\text {nd }}$ stream - low quantity of long messages (for example, video download, when the servicing speed is not important).

Let us illustrate the aforementioned servicing model, using four servicing disciplines, by the unified QS (Fig.2), where the variables $\lambda_{12}, \mu_{21}$ and $\mu_{22}$ are the instruments of priority system situational control.

1. Given $\lambda_{12}=0, \mu_{21}=1, \mu_{22}=0$ we have the system without priorities.

2. The system with the relative priority should fulfill these conditions: $\lambda_{12}=\lambda_{1}, \mu_{21}=\mu_{2}, \mu_{22}=0$. 
3. The system with the absolute priority should fulfill these conditions:

$$
\lambda_{12}=\lambda_{1}, \mu_{21}=\infty, \mu_{22}=0 .
$$

4. The re-servicing system: $\lambda_{12}=\lambda_{1}, \mu_{21}=0, \mu_{22}=$ $\mu_{1}$.

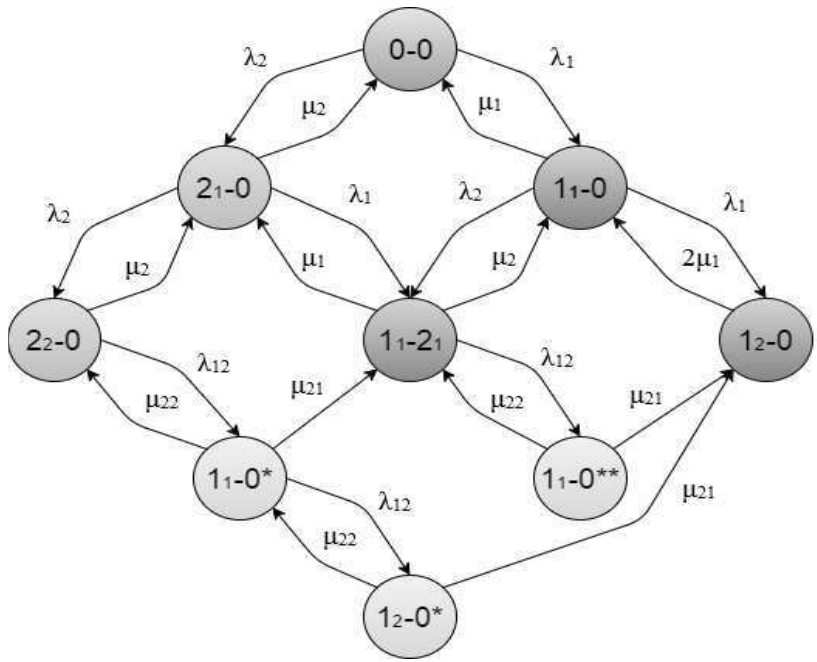

Fig.2 Unified QS with two streams and two servicing devices

Let us illustrate the productivity for every discipline and find the better one to fulfill our scenario (see Fig. 3, Fig. 4).

In Fig. 3 we designate the productivity as Yxy, where $x$ is one of the four servicing disciplines $(1-$ without priorities, 2 - relative, 3 - absolute, 4 - reservicing), $y$ is the stream ( 1 - of the first one, $2-$ of the second). The productivities for the second stream are shown in dashed lines.

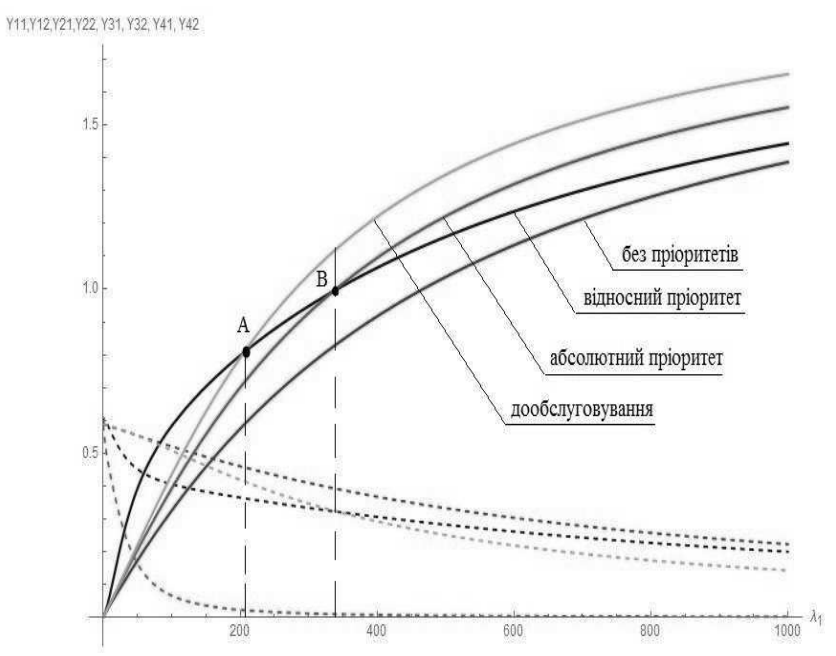

Fig. 3 The productivities of the $1^{\text {st }}$ and $2^{\text {nd }}$ streams for the 4 servicing disciplines
Fig.4 illustrates how the total productivity depends on $\lambda_{1}$ for 4 servicing disciplines.

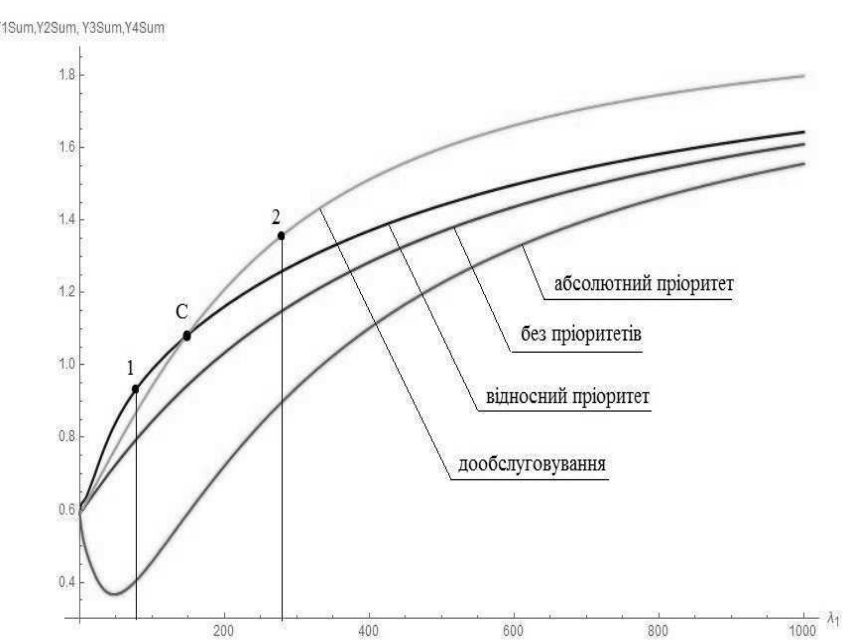

Fig.4 Total productivity for 4 servicing disciplines.

By analyzing Fig.3 we can conclude that, the best discipline for servicing the $1^{\text {st }}$ stream in this scenario is the relative priority until $\lambda_{1}=202,4$ requests/hour (breaking point), then re-servicing becomes the best discipline; the worst is discipline without priorities.

The discipline without priorities is the best for servicing the $2^{\text {nd }}$ stream, while the worst is absolute priority, which is anticipated, because the absolute priority is the most harsh to the second stream which has lower priority than the first stream.

Fig.3 shows that the relative priority has the leading value of total productivity, but after $\lambda_{1}=144,7$ requests/hour (breaking point) the re-servicing becomes more appropriate. The discipline with absolute priority is the worst, despite that for the $1^{\text {st }}$ stream absolute priority works effectively, denying the requests from the $2^{\text {nd }}$ priority for servicing only the $1^{\text {st }}$ stream.

\section{Conclusion}

1. The QS class was considered here, where the priority servicing mechanism is a tool for solving conflicts related to the requests servicing resource limitations due to the different significance or nature of messages. The SP disciplines are the separate group of QSs — the real-time priority discipline choice in depends on the current state of QS.

2. The generalized servicing model for two streams and one or two servicing devices and the possible SP servicing in access systems implementation scenarios were proposed..

3. The productivities for every stream and the total system productivity were analyzed. 
4. One of the possible SP algorithm implementation scenarios was proposed based on the analyzed mathematical model of telecommunication system resource access. There are points of priority change control by the given value - total QS productivity, in particular, points $\mathrm{A}$ and $\mathrm{B}$ (Fig. 3) and point C (Fig. 4).

\section{References}

1. Kleinrock L. Theory of Queuing system: Volume I -. New York: Wiley Interscience, 1975. - 417 p.

2. Mova V. Organization of priority maintenance in the automated control system / Mova V., Ponomarenko L., Kalinovsky A.. Kyiv: Technica, 1977. - $160 \mathrm{p}$.

3. Uryvsky L. The generalization of the "reproduction and death" process of systems with "access conflict" // Scientific Proceeding of Ukrainian Research Institute of Communication. - 2009. - № 1. - C. 97-104.

4. Uryvsky L., Hakhova $\mathrm{H}$. The generalization of the queuing system with priority // - K.: ITS NTUU "KPI", IX International STC «Problems in telecommunication», Sourcebook. -2015 , p.p. 77-79

Received in final form on May 10, 2017

\section{Уривський Л. О., Гахова Г.С.}

\section{Узагальнена модель використання ситуаційних пріоритетів в системах доступу}

Мета досліджень. В умовах обмежених ресурсів системи масового обслуговування (СМО) обслуговування 3 дисциплінами різних пріоритетів $\epsilon$ потужним інструментом подолання конфліктів. Метою даної роботи $\epsilon$ узагальнення моделі ситуаційного пріоритетного обслуговування на прикладі СМО з двома потоками для випадків одного і двох приладів обслуговування, а також пропозиція можливих сценаріїв реалізації ситуаційних пріоритетів у системах доступу.

Методика реалізації. На підставі використання теорії марківських ланцюгів реалізована узагальнена аналітична модель системи масового обслуговування. Отримана модель дозволяє обгрунтувати кращі сценарії реалізації ситуаційних пріоритетів.

Результати досліджень. Результатом є аналітичний опис узагальненої моделі СМО з двома потоками для випадків одного і двох приладів обслуговування, а також кількісний аналіз сценаріїв реалізації ситуаційних пріоритетів обслуговування в системах доступу. Проведено аналіз продуктивності для кожного потоку і сумарної продуктивності СМО. Запропоновано рекомендації для ефективного використання дисциплін пріоритетного обслуговування для розглянутих сценаріїв.

Висновки. На основі проаналізованої математичної моделі доступу до ресурсів телекомунікаційної системи запропонований один з можливих сценаріїв реалізації алгоритмів ситуаційних пріоритетів. На підставі кількісних даних проілюстровані точки управління зміною виду пріоритету на користь обраного показника - продуктивності системи.

Ключові слова: системи доступу; системи масового обслуговування; ситуаційні пріоритети; продуктивність.

\section{Урывский Л. А., Гахова А.С.}

\section{Обобщенная модель использования ситуационных приоритетов в системах доступа}

Цель исследований. В условиях ограниченных ресурсов систем массового обслуживания (СМО) обслуживание с дисциплинами различных приоритетов являются мощным инструментом преодоления конфликтов. Целью данной работы является обобщение модели ситуационного приоритетного обслуживания на примере СМО с двумя потоками для случаев одного и двух приборов обслуживания, а также предложение возможных сценариев реализации ситуационных приоритетов в системах доступа.

Методика реализации. На основании использования теории марковских цепей реализована обобщенная аналитическая модель системы массового обслуживания. Полученная модель позволяет обосновать предпочтительные сценарии реализации ситуационных приоритетов.

Результаты исследований. Результатом является аналитическое описание обобщенной модели СМО с двумя потоками для случаев одного и двух приборов обслуживания, а также количественный анализ сценариев реализации ситуационных приоритетов обслуживания в системах доступа. Проведен анализ производительности для каждого потока и суммарной производительности СМО. Предложены рекомендации для эффективного использования дисциплин приоритетного обслуживания для рассмотренных сценариев.

Выводы. На основе проанализированной математической модели доступа к ресурсам телекоммуникационной системы предложен один из возможных сценариев реализации алгоритмов ситуационных приоритетов. На основании количественных данных проиллюстрированы точки управления изменением вида приоритета в пользу выбранного показателя - производительности системы.

Ключевые слова: системы доступа; системы массового обслуживания; ситуационные приоритеты; производительность. 